\section{NTS 2020/51}

\author{
HR 7 januari 2020, 18/03180, ECLI:NL:HR:
}

2020:2

Oplegging ISD-maatregel voor mishandeling en diefstallen. Vereisten voor kmalificatie als 'zeer actieve veelpleger' a.b.i. art. $2 . b$ van de Richtlijn voor Strafvordering bij meerderjarige veelplegers.

\section{Aantekening redactie}

De Richtlijn voor Strafvordering bij meerderjarige veelplegers (in het bijzonder de vordering van de ISD-maatregel bij stelselmatige daders) is een aanwijzing als bedoeld in artikel 130 lid 4 Wet RO. De Richtlijn moet worden beschouwd als 'recht' in de zin van artikel 79 Wet RO. Deze Richtlijn bevat immers door het College van procureurs-generaal vastgestelde en behoorlijk bekendgemaakte regels omtrent de uitoefening van het beleid van het openbaar ministerie, die weliswaar niet kunnen gelden als algemeen verbindende voorschriften omdat zij niet krachtens enige wetgevende bevoegdheid zijn gegeven, maar die het openbaar ministerie wel op grond van beginselen van behoorlijke procesorde binden, en die zich naar hun inhoud en strekking ertoe lenen jegens betrokkenen als rechtsregels te worden toegepast. ${ }^{44}$

In de hier te bespreken zaak is de verdachte door het hof wegens 1. 'diefstal', 2. 'mishandeling' en in de zaken met parketnummers 03/700254-16 en 03/700285-16, telkens 'diefstal', veroordeeld tot de maatregel van plaatsing in een inrichting voor stelselmatige daders voor de duur van twee jaar. Het middel klaagde dat het hof ten onrechte, althans ontoereikend gemotiveerd, de maatregel tot plaatsing van de verdachte in een inrichting voor stelselmatige daders heeft opgelegd, omdat het hof bij de beoordeling of sprake is van een 'zeer actieve veelpleger' ten onrechte de bewezen verklaarde gevoegde misdrijffeiten in de zaken met de parketnummers 03/700254-16 en 03/700463-15 heeft meegewogen. Volgens de Richtlijn kan een ISD-maatregel worden opgelegd aan zeer actieve veelplegers die aan een aantal voorwaarden voldoen. Een zeer actieve veelpleger in de zin van voornoemde richtlijn is een persoon van 18 jaar of ouder die over een periode van vijf jaar processenverbaal tegen zich opgemaakt zag worden voor meer dan tien misdrijffeiten, waarvan ten minste één misdrijf in de laatste twaalf maanden, terug te rekenen vanaf de pleegdatum van het laatst gepleegde misdrijffeit. De vraag in de onderhavige zaak is of aan de eis dat ten minste één misdrijf in de laatste twaalf maanden, terug te rekenen vanaf de pleegdatum van het laatst gepleegde misdrijf, is voldaan. Was de opvatting van de verdediging dat gevoegde misdrijffeiten niet mogen meetellen bij de invulling van het vereiste van ten minste één misdrijf in de laatste twaalf maanden, teruggerekend vanaf de pleegdatum van het laatst gepleegde misdrijffeit, nu daarvoor geen steun is te vinden in (de bewoordingen van) de Richtlijn, juist? De Hoge Raad oordeelde dat die opvatting onjuist is:

'Ingevolge art. 38m, eerste lid, Sr kan de rechter de ISD-maatregel slechts opleggen op vordering van het openbaar ministerie. Gelet op onder meer de strikte afgrenzing die de Richtlijn aanbrengt ten aanzien van de gevallen waarin plaats is voor het vorderen van de ISD-maatregel, staan beginselen van behoorlijke rechtspleging eraan in de weg dat de rechter, indien hij vaststelt dat een dergelijke vordering is gedaan in strijd met de Richtlijn, niettemin de ISD-maatregel oplegt (vgl. HR 7 juli 2009, ECLI:NL:HR: 2009:BH9943). De Richtlijn vermeldt een aantal eisen waaraan moet zijn voldaan, voordat sprake is van een 'zeer actieve veelpleger' als bedoeld in deze Richtlijn tegen wie de oplegging van de ISD-maatregel kan worden gevorderd. Eén van deze eisen is dat over een periode van vijf jaren processen-verbaal zijn opgemaakt tegen de verdachte voor meer dan tien misdrijffeiten, waarvan ten minste één misdrijf in de laatste twaalf maanden, terug te rekenen vanaf de pleegdatum van het laatst gepleegde misdrijffeit. Het middel berust op de opvatting dat bij de beoordeling of is voldaan aan de onder 2.5.2 genoemde eis, strafbare feiten die gevoegd aanhangig zijn gemaakt of waarvan op de terechtzitting de voeging is bevolen (en waarvan niet is vrijgesproken), niet mogen worden meegeteld. Die opvatting is onjuist.' 